\title{
Ring opening metathesis polymerization of bisnorbornene derivatives linked by $\mathrm{Cp}_{2} \mathrm{Ni}_{2}(\mu-\mathrm{S})_{2}$ bridge
}

\author{
Hui-Chun Yang ${ }^{\text {a,b }}$, Shiu-Mei Lin ${ }^{\text {c,d }}$, Yi-Hung Liu ${ }^{\text {a }}$, Yu Wang ${ }^{\text {a }}$, Mei-Man Chen ${ }^{d}$, \\ Hwo-Shuenn Sheu ${ }^{\mathrm{e}}$, Der-Lii Tsou ${ }^{\mathrm{d}}$, Chih-Hsiu Lin ${ }^{\mathrm{d}}$, Tien-Yau Luh ${ }^{\mathrm{a}, *}$ \\ a Department of Chemistry, National Taiwan University, Taipei 106, Taiwan \\ ${ }^{\mathrm{b}}$ Institute of Polymer Science and Engineering, National Taiwan University, Taipei 106, Taiwan \\ ${ }^{c}$ Institute of Bioscience and Biotechnology, National Taiwan Ocean University, Keelung 202, Taiwan \\ ${ }^{\mathrm{d}}$ Institutes of Chemistry, Academia Sinica, Nangang, Taipei 115, Taiwan

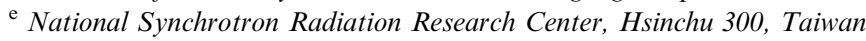

Received 10 March 2006; received in revised form 28 March 2006; accepted 30 March 2006

Available online 6 April 2006

\begin{abstract}
ROMP of 2 with Grubbs I catalyst in $\mathrm{CH}_{2} \mathrm{Cl}_{2}$ furnished the corresponding polymer $\mathbf{5}$ which was characterized by spectroscopic means, particularly, MAS ${ }^{13} \mathrm{NMR}$. The EXAFS of 5 results were compared with those of the monomeric starting material 2 and the X-ray data of 2.

(C) 2006 Elsevier B.V. All rights reserved.
\end{abstract}

Keywords: Ring opening metathesis polymerization; Bisnorbornene; $\mathrm{Ni}_{2} \mathrm{~S}_{2}$; EXAFS; Crystal structure

\section{Introduction}

Ring opening metathesis polymerization (ROMP) of cyclic alkene derivatives has provided unique protocol for the synthesis of a range of polymers that are not readily accessible by other polymerization methods [1]. Polymers and block copolymers of norbornene derivatives having a variety of substituents are prepared conveniently [1,2]. ROMPs of bisnorbornene derivatives have briefly explored $[3,4]$. We recently reported the first double stranded helical polymer 1 by ROMP of a bisnorbornene derivative linked by a ferrocene moiety (Scheme 1) [4]. The key to success of this approach relies on the coherent alignment of the endo pending groups in the ROMP of the norbornene derivatives [5]. In addition, the relatively rigid but slightly flexible ferrocene-derived linker may accommodate appropriate

\footnotetext{
${ }^{*}$ Corresponding author. Tel.: +886223636288 ; fax: +886223644971.

E-mail address: tyluh@ntu.edu.tw (T.-Y. Luh).
}

orientation of the second norbornene moiety for polymerization. It is interesting to note that the distance (ca. $5 \AA$ ) between two neighboring iron atoms in $\mathbf{1}$ is comparable with those in single crystals of ferrocene derivatives [6]. Presumably, interactions between the linkers may generate a favorable stereochemical requirement for the formation of the double stranded polymer $\mathbf{1}$.

Square planar $\mathrm{Cp}_{2} \mathrm{Ni}_{2}(\mathrm{SR})_{2}$ complexes are well documented and the $\mathrm{Ni}_{2} \mathrm{~S}_{2}$ moiety is arranged as a rigid square [7]. It is envisaged that the alkyl substituent in this complex can be a norbornene moiety (e.g. 2). In this paper, we wish to report the synthesis and ROMP of organonickel-linked bisnorbornene 2 .

\section{Results and discussion}

Monomeric bisnorbornene derivative 2 was designed by incorporating a slightly labile benzylic moiety which would allow some flexibility during the course of polymerization step. Thus, the monomeric bisnorbornene derivative $\mathbf{2}$ 


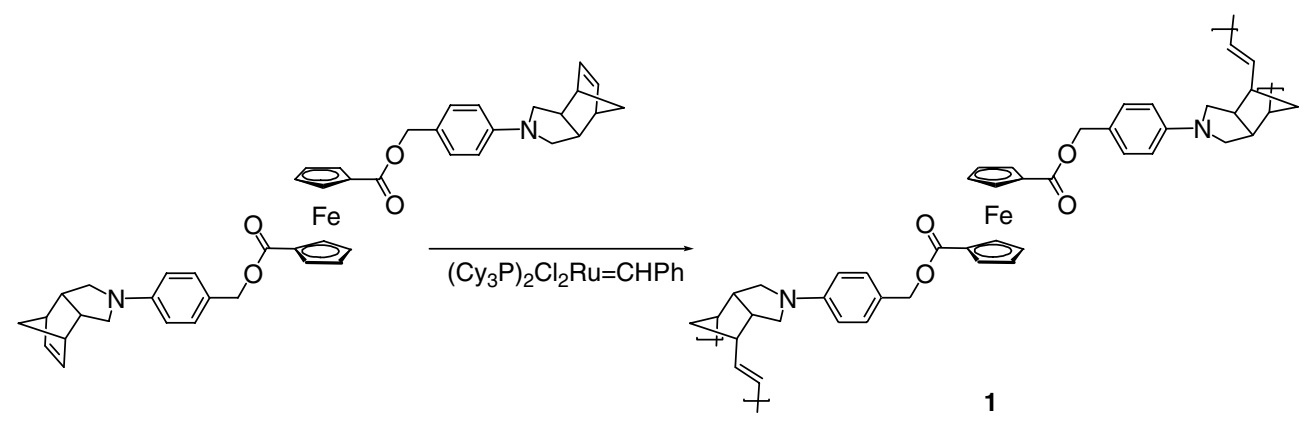

Scheme 1.

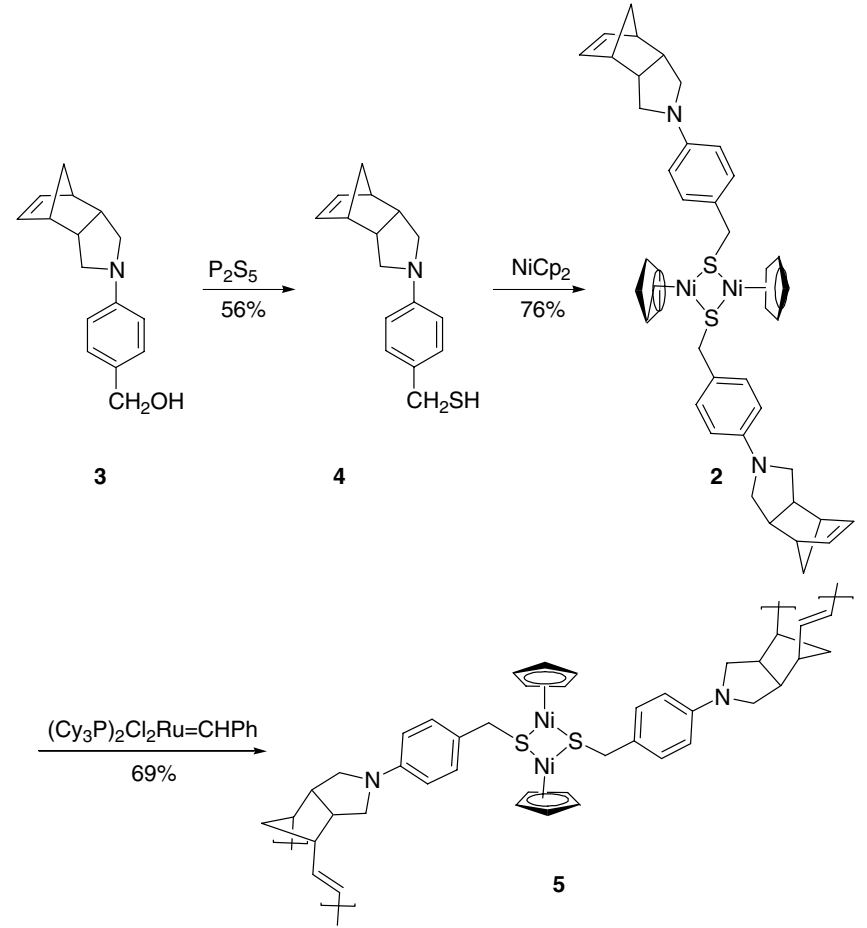

Scheme 2 .

was synthesized according to Scheme 2. Treatment of benzylic alcohol 3 with $\mathrm{P}_{2} \mathrm{~S}_{5}$ [8] afforded the corresponding mercaptan 4 in $56 \%$ yield. Reaction of 4 with nickelocene [7] gave $\mathbf{2}$ in $76 \%$ yield as a black solid. The X-ray structure of $\mathbf{2}$ suggested that the molecule has a center of symmetry and the two norbornene moieties are in anti conformation in the crystal (Fig. 1). The packing of $\mathbf{2}$ in the single crystal is also shown in Fig. 1.

ROMP of 2 with Grubbs I catalyst [9] in $\mathrm{CH}_{2} \mathrm{Cl}_{2}$ furnished the corresponding polymer $\mathbf{5}$ in $69 \%$ yield. Unlike ferrocene derivatives, polymer $\mathbf{5}$ was insoluble in any organic solvent. Polymer $\mathbf{5}$ exhibited an absorption band at $968 \mathrm{~cm}^{-1}$ which is characteristic for trans carbon-carbon double bond. This band was absent in the starting 2 . ROMPs of norbornene derivatives with Grubbs I catalyst are known to give predominantly, if not exclusively, trans double bond $[1,4,5]$. The infrared data suggested that ROMP might take place with 2 .
As can be seen in Fig. 2, the MAS ${ }^{13} \mathrm{C}$ NMR spectrum of $\mathbf{5}$ is very similar to that of $\mathbf{2}$. The energy dispersive spectrometric (EDS) analysis indicated that the ratio of nickel to sulfur was 56 to 44 . The ICPMS also confirmed the presence of nickel in 5. These results suggested that the $\mathrm{Cp}_{2} \mathrm{Ni}_{2} \mathrm{~S}_{2}$ core might remain intact during the course of ROMP process.

The EXAFS spectra of $\mathbf{2}$ and $\mathbf{5}$ are shown in Fig. 3. The high intensity peaks at 200 and $300 \mathrm{pm}$ owing to the interactions of heavy atoms in the $\mathrm{Ni}_{2} \mathrm{~S}_{2}$ core were observed for both $\mathbf{2}$ and $\mathbf{5}$. These results again indicated that the $\mathrm{Ni}_{2} \mathrm{~S}_{2}$ core remained intact during the course of polymerization. In addition to these main absorptions at shorter distances, there are also weak long range weak interactions of heavy atoms at 535 and $625 \mathrm{pm}$ for $\mathbf{5}$. These results suggested that the two neighboring $\mathrm{Ni}_{2} \mathrm{~S}_{2}$ cores may be in close proximity and these distances happen to fall within the span of each monomeric unit in polynorbornenes, which ranges from 500 to $650 \mathrm{pm}$ $[4,5]$. Such long range interactions are, in general, difficult to analyze unless there is a closely related model where the interatomic distances are in the same range. As shown in Fig. 1b, the closest intermolecular $\mathrm{Ni}-\mathrm{Ni}$ distances in the single crystal of 2 were 535 and $610 \mathrm{pm}$ and the intermolecular Ni-S distances were 526 and $615 \mathrm{pm}$. These distances were reflected as week peaks in the EXAFS spectrum for 2 (Fig. 3a). Accordingly, the EXAFS results for 2 may support the presence of long range interactions between heavy atoms in $\mathbf{5}$. When such interactions are persistent along the polymeric chain, one of the possibilities would be that polymer 5 might also adopt a double stranded structure in a manner similar to that of the analogues with ferrocene linker 1 [4].

\section{Conclusions}

In summary, we have demonstrated the synthesis and polymerization of a $\mathrm{Ni}_{2} \mathrm{~S}_{2}$ linked bisnorbornene derivative 2. Although further evidences will be necessary, the preliminary results thus obtained suggested that the polymer 5 might adopt a double stranded structure. Further investigations by designing other linkers as well as other monomeric species having different kinds of cyclic alkenes are in progress. 
(a)
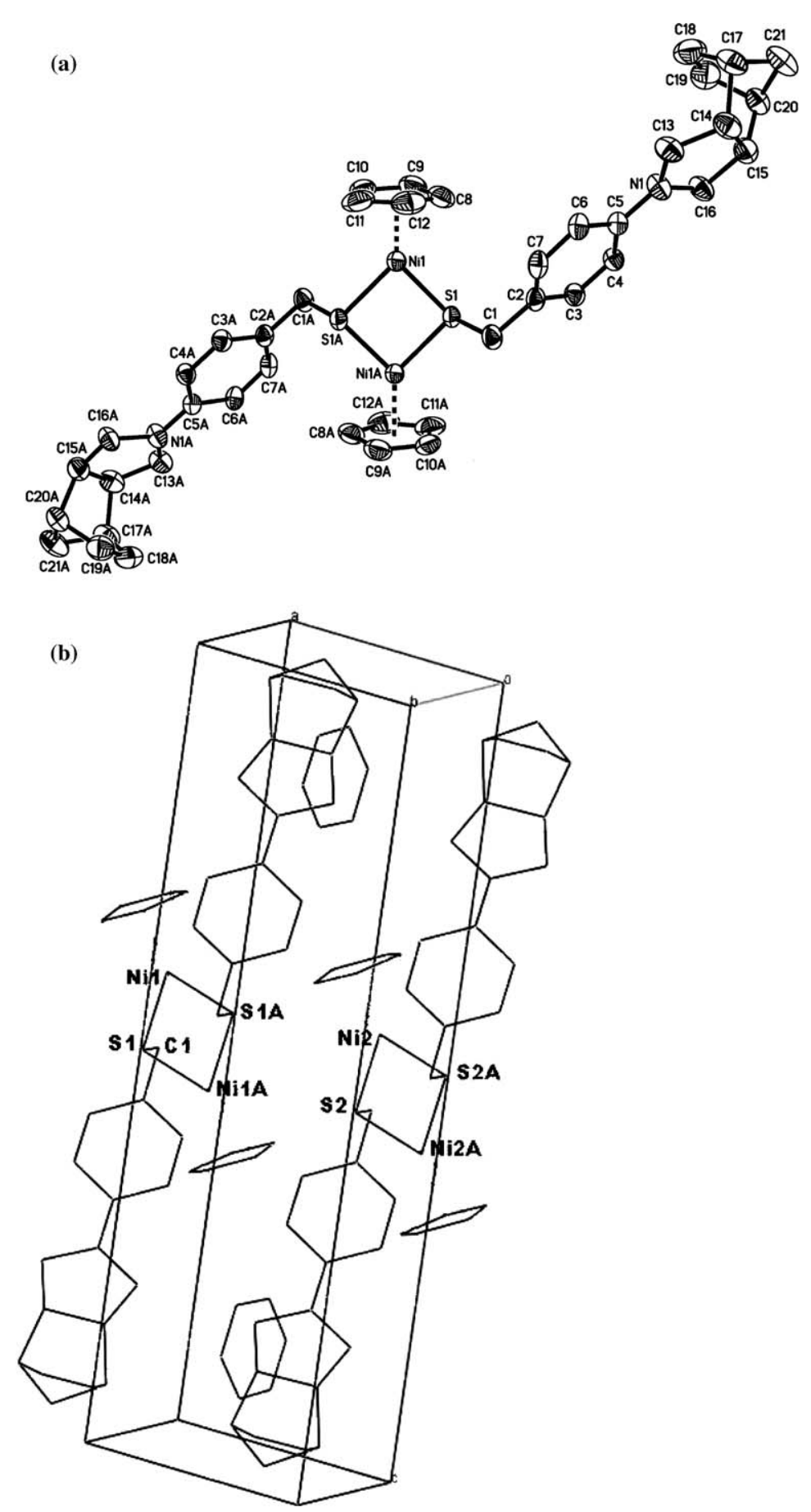

Fig. 1. (a) ORTEP view of $\mathbf{2}$ showing the atom labeling scheme (50\% thermal ellipsoids). Selected crystal data for 2: Triclinic, space group $P \overline{1}$, unit cell dimensions $\left(a=6.10600(10) \AA, b=9.9040(2) \AA, c=20.0100(4) \AA, \alpha=92.7140(10)^{\circ}, \beta=93.7810(10)^{\circ}, \gamma=104.8620(10)^{\circ}\right) V_{0}$ olume $1164.46(4) \AA^{3}, Z=1$, density (calculated) $1.307 \mathrm{Mg} / \mathrm{m}^{3}$. (b) Crystal packing pattern of 2 . Each unit cell contains two molecules of benzene. Selected interatomic distances and angles in the crystal of 2 : Ni1-S1 $=217.5 \mathrm{pm}, \mathrm{Ni1}-\mathrm{S} 1 \mathrm{~A}=217.8 \mathrm{pm}, \mathrm{C} 1-\mathrm{S} 1=185 \mathrm{pm}, \mathrm{Ni1}-\mathrm{Ni1} \mathrm{A}=313 \mathrm{pm} ;$ angle S1-Ni1-S1A $=88.2^{\circ}, \mathrm{Ni1A}-\mathrm{S} 1-$ $\mathrm{Ni} 1=91.8^{\circ}$. Selected distances and angles between two molecules of 2 in the single crystal: Ni1-Ni2 $=611 \mathrm{pm}, \mathrm{Ni} 1-\mathrm{Ni} 2 \mathrm{~A}=535 \mathrm{pm}, \mathrm{Ni} 1-\mathrm{S} 2=526 \mathrm{pm}$, $\mathrm{Ni1}-\mathrm{S} 2 \mathrm{~A}=615 \mathrm{pm}, \mathrm{S} 2-\mathrm{S} 1 \mathrm{~A}=602 \mathrm{pm}, \mathrm{S} 1-\mathrm{Ni2}=526 \mathrm{pm}$; angle Ni1A-Ni1-Ni2 = 61.1 ${ }^{\circ}, \mathrm{Ni1}-\mathrm{Ni} 2-\mathrm{Ni2A}=118.9^{\circ}$.

\section{Experimental}

\section{1. [4-(4-Aza-tricyclo[5.2.1.02,6]dec-8-en-4-yl)-phenyl]- methanethiol (4)}

Under argon atmosphere, a mixture of benzyl alcohol 3 $(1.22 \mathrm{~g}, 5 \mathrm{mmol})$ and $\mathrm{P}_{2} \mathrm{~S}_{5}(2.67 \mathrm{~g}, 12 \mathrm{mmol})$ in pyridine
$(20 \mathrm{~mL})$ was stirred at r.t. for $1 \mathrm{~h}$ and then cooled in ice bath. Water $(60 \mathrm{~mL})$ was added and the solid was collected, washed with water and then dissolved in THF and dried $\left(\mathrm{MgSO}_{4}\right)$. The solvent was evaporated in vacuo and the residue was chromatographed on silica gel (EtOAc/hexane $=5 / 95)$ to give $\mathbf{4}$ as a white solid $(0.72 \mathrm{~g}, 56 \%)$ : m.p. 76-78 ${ }^{\circ} \mathrm{C}$; IR (KBr): 3067, 2949, 2839, 2568, 1616, 1521, 


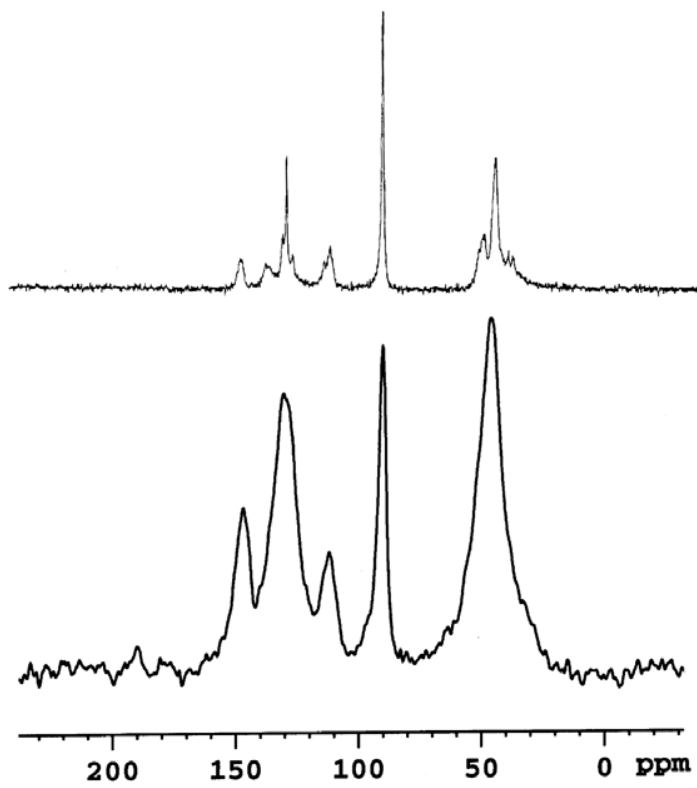

Fig. 2. MAS ${ }^{13} \mathrm{C}$ NMR spectra of (a) 2 and (b) 5 .
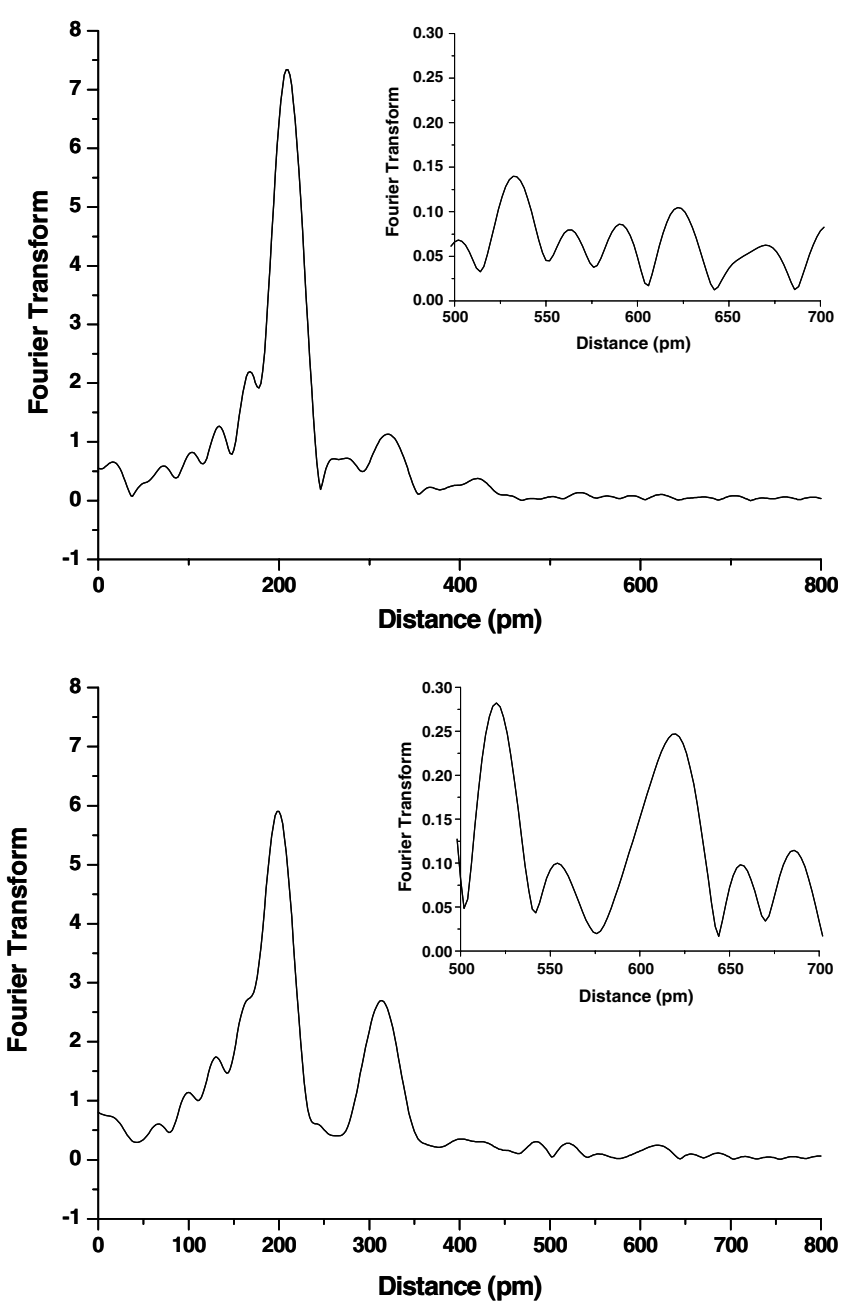

Fig. 3. Fourier transform $\left(k^{3}\right.$ weighted, $\mathrm{Ni}-\mathrm{C}$ phase corrected, $\Delta k=3.5$ 13.0 $\AA^{-1}$ ) of EXAFS data for (a) 2 .and (b) 5 . $1478,1367,1345,1189,814,722\left(\mathrm{~cm}^{-1}\right) ;{ }^{1} \mathrm{H}$ NMR $(400 \mathrm{MHz}): \quad \delta \quad 1.48 \quad(\mathrm{~d}, \quad J=8.4 \mathrm{~Hz}, \quad 1 \mathrm{H}), \quad 1.51 \quad(\mathrm{~d}$, $J=8.4 \mathrm{~Hz}, 1 \mathrm{H}), 1.64(\mathrm{t}, \quad J=7.1 \mathrm{~Hz}, 1 \mathrm{H}), 2.85 \quad(\mathrm{dd}$, $J=9.5,2.9 \mathrm{~Hz}, 2 \mathrm{H}), 2.94-2.94(\mathrm{~m}, 2 \mathrm{H}), 3.02-3.06(\mathrm{~m}$, $2 \mathrm{H}), 3.17-3.21(\mathrm{~m}, 2 \mathrm{H}), 3.64(\mathrm{~d}, J=7.1 \mathrm{~Hz}, 2 \mathrm{H}), 6.11-$ $6.13(\mathrm{~m}, 2 \mathrm{H}), \quad 6.36(\mathrm{~d}, \quad J=8.6 \mathrm{~Hz}, 2 \mathrm{H}), 7.10(\mathrm{~d}$, $J=8.6 \mathrm{~Hz}, 2 \mathrm{H}) ;{ }^{13} \mathrm{C}$ NMR $(100 \mathrm{MHz}): \delta 28.7,45.5,46.5$, $50.6,52.2,112.0,127.6,128.8,135.8,146.8 ; \mathrm{MS}(70 \mathrm{eV})$ $\mathrm{m} / \mathrm{z}$ (rel. intensity) $257(\mathrm{M}+, 3), 225$ (4), 224 (12), 198 (100), 197 (45), 184 (3), 182 (14), 167 (3), 158 (11), 154 (3), 152 (3), 128 (2), 106 (3), 98 (5), 91 (7), 77 (3), 65 (2), 51 (2); HRMS: Calcd. 257.1238; Found: 257.1237; Anal. Calc. for $\mathrm{C}_{16} \mathrm{H}_{19} \mathrm{NS}$ : C, 74.66, H, 7.44, N, 5.44; Found: C, 74.73, H, 7.33 , N, 5.36\%.

\subsection{Monomer (2)}

Under argon atmosphere, a solution of $4(2.4 \mathrm{~g}$, $9.4 \mathrm{mmol})$ in benzene $(25 \mathrm{~mL})$ was added into a solution of nickelocene $(2.0 \mathrm{~g}, 10.4 \mathrm{mmol})$ in benzene $(200 \mathrm{~mL})$. The mixture was stirred for $16 \mathrm{~h}$ at r.t. The solution was concentrated to saturation and the flask was immersed in an ice bath to give the black solid which was washed with pentane to afford 5 as a black solid $(5.4$ g, 76\%): m.p. 156$158^{\circ} \mathrm{C}$; IR (KBr): $3061,2958,2832,1616,1513,1474,1363$, 1347, 1189, 771, 716, 518, 468, 436, 379, 312, 287; ${ }^{1} \mathrm{H}$ NMR (400 MHz): $\delta 1.47(\mathrm{~d}, J=8.6 \mathrm{~Hz}, 2 \mathrm{H}), 1.57(\mathrm{~d}, J=8.6 \mathrm{~Hz}$, 2H), 2.81-2.84 (m, 4H), 2.93 (bs, 4H), 3.03-3.03 (m, 4H), $3.16-3.20(\mathrm{~m}, 4 \mathrm{H}), 3.31(\mathrm{bs}, 4 \mathrm{H}), 4.47(\mathrm{~s}, 10 \mathrm{H}), 6.11(\mathrm{~s}$, $4 \mathrm{H}), 6.31(\mathrm{~d}, J=8.1 \mathrm{~Hz}, 4 \mathrm{H}), 7.07(\mathrm{~d}, J=8.1 \mathrm{~Hz}, 4 \mathrm{H})$; ${ }^{13} \mathrm{C}$ NMR (100 MHz): $\delta 37.6,45.5,46.4,50.7,52.1,91.9$, 111.5, 127.6, 129.4 135.8, 146.7; MS (FAB) $\mathrm{m} / z$ (rel. intensity) $758(\mathrm{M}+, 4), 693$ (1), 613 (2), 460 (10), 443 (2), 391 (4), 307 (72), 289 (32), 224 (100); HRMS: Cacld. 758.1808; Found: 758.1801. The single crystal for the X-ray crystallographic study was obtained from a pentane/benzene (3/2) solution.

\subsection{Polymer (5)}

Under argon atmosphere, a solution of $5 \mathrm{~mol} \%$ Grubb I catalyst $(5.4 \mathrm{mg}, 0.006 \mathrm{mmol})$ in $\mathrm{CH}_{2} \mathrm{Cl}_{2}(2 \mathrm{~mL})$ was added to $5(100 \mathrm{mg}, 0.13 \mathrm{mmol})$ in $\mathrm{CH}_{2} \mathrm{Cl}_{2}(5 \mathrm{~mL})$. The mixture was stirred at r.t. for $30 \mathrm{~min}$ and quenched with ethyl vinyl ether. The mixture was poured into $\mathrm{MeOH}(20 \mathrm{~mL})$ and the solid was collected and washed with $\mathrm{CH}_{2} \mathrm{Cl}_{2}$ and ether to yield $\mathbf{5}$ as a black solid $(0.52 \mathrm{~g}, 69 \%)$ : IR $(\mathrm{KBr}) 2934$, 2850, 1595, 1521, 1479, 1447, 1371, 1168, 1037, 968, 816, 725, 670, 630; MAS ${ }^{13} \mathrm{C}$ NMR $\delta 50,90,112,132,149$.

\subsection{Extended X-ray absorption spectroscopy (EXAFS)}

All X-ray absorption spectra of the Ni K edge $(8333 \mathrm{eV})$ were measured on the beam line BL17C at the Synchrotron Radiation Research Center (SRRC) in Hsinchu, Taiwan, with a storage ring energy $1.5 \mathrm{GeV}$ and a beam current between 120 and $200 \mathrm{~mA}$. The EXAFS measurements were 
performed in transmission mode at the X-ray Wiggler beam line with a double-crystal $\mathrm{Si}(111)$ monochromator. The higher X-ray harmonics were minimized by detuning the double-crystal monochromator to $80 \%$ of the maximum. The ion chambers used for measuring the incident $\left(I_{0}\right)$ and transmitted $(I)$ synchrotron beam intensities were filled with a mixture of $\mathrm{N}_{2}$ and $\mathrm{He}$ gases and a mixture $\mathrm{N}_{2}$ and Ar gases, respectively. Moreover, to ensure reliability of the spectra, the spectrum of Ni metal foil was also monitored to evaluate the stability of the energy scale for each measurement. Data reduction and data analysis were performed with the XDAP code developed by Vaarkamp et al. [10]. Standard procedures were used to extract the EXAFS data from the measured absorption spectra. The pre-edge was approximated by a modified Victoreen curve [11] and the background was subtracted using cubic spline routines $[12,13]$. Normalization was performed by dividing the data by the height of the absorption edge at $50 \mathrm{eV}$ above the edge [11]. Phase shifts and backscattering amplitudes functions of $\mathrm{Ni}-\mathrm{C}, \mathrm{Ni}-\mathrm{S}$ and $\mathrm{Ni}-\mathrm{Ni}$ were used as reference files to analyze the EXAFS data. The reference functions of $\mathrm{Ni}-\mathrm{C}, \mathrm{Ni}-\mathrm{S}$ and $\mathrm{Ni}-\mathrm{Ni}$ are generated by FEFF7 code [14].

\subsection{X-ray crystallographic structure of 2}

Diffraction measurements were made on a Nonius KappaCCD diffractometer with graphite-monochromated Mo K $\alpha$ radiation $(\lambda=0.71073 \AA)$, operating at $295 \mathrm{~K}$, over the $\theta$ range $2.04-27.46^{\circ}$. No significant decay was observed during the data collection. Reflections (4429) were observed with $I \geqslant 2 \sigma(I)$ among the 5264 unique reflections, and 5244 reflections were used in the refinement. Data were processed on a PC using the SHELXTL software package. The structure of $\mathbf{2}$ was solved using the direct method and refined by full-matrix least squares on the $F^{2}$ value. All non-hydrogen atoms were refined anisotropically. The positions of hydrogen atoms were identified by calculation, and their contributions to structure factors were included. The final indices were $R_{1}=0.0439, w R_{2}=0.1248$ with goodness-of-fit on $F^{2}=1.088$.

\subsection{ICPMS measurement}

Polymer 5 was digested with concentrated nitric acid and subjected to ICPMS analysis of nickel on a SCIEX ELAN 600 ICP-MS (Perkin-Elmer) with cross flow nebuliser for sample introduction.

\subsection{EDS measurement}

Energy dispersion spectrometric analysis was performed on an SEM (JSM-5400) equipped with and EDS facility (EDX-Oxford Link ISIS (Modle EXL3).

\section{Acknowledgments}

This work is supported by the Naitonal Science Council of the Republic of China. We thank Dr. L.-H. Huang and Ms. M.-Y. Chung for carrying out ICPMS and energy dispersion spectroscopy measurements.

\section{References}

[1] R.H. Grubbs (Ed.), Handbook of Metathesis, vol. 3, Wiley-VCH, Weinheim, 2003

[2] R. Madan, A. Srivastava, R.C. Anand, I.K. Varma, Prog. Polym. Sci 23 (1998) 621.

[3] (a) D.C. Braddock, D. Chadwick, E. Lindner-Lòpez, Tetrahedron Lett. 45 (2004) 9021;

(b) P.J. Hine, T. Leejarkpai, E. Khosravi, R.A. Duckett, W.J. Feast, Polymer 42 (2001) 9413;

(c) H. Nakade, M.F. Ilker, B.J. Jordan, O. Uzun, N.A. LaPointe, E.B. Coughlin, V.M. Rotello, Chem. Commun. (2005) 3271.

[4] H.-C. Yang, S.-Y. Lin, H.-C. Yang, C.-L. Lin, L. Tsai, S.-L. Huang, I-W.P. Chen, C.-h. Chen, B.-Y. Jin, T.-Y. Luh, Angew. Chem., Int. Ed. 45 (2006) 726.

[5] W.-Y. Lin, M.G. Murugesh, S. Sudhakar, H.-C. Yang, H.-C. Tai, C.-S. Chang, Y.-H. Liu, Y. Wang, I.-W.P. Chen, C.-h. Chen, T.-Y. Luh, Chem. Eur. J. 12 (2006) 324.

[6] (a) J.D. Dunitz, L.E. Orgel, A. Rich, Acta Crystallogr. 9 (1956) 373 ;

(b) D.M. Shin, I.S. Lee, Y.K. Chung, Eur. J. Inorg. Chem (2003) 2311;

(c) A. Dirksen, U. Hahn, F. Schwanke, M. Nieger, J.N.H. Reek, F. Vögtle, L.D. Cola, Chem. Eur. J. 10 (2004) 2036.

[7] (a) N.-F. Ho, T.C.W. Mak, T.-Y. Luh, J. Organomet. Chem. 317 (1986) C28;

(b) N.-F. Ho, T.C.W. Mak, T.-Y. Luh, J. Chem. Soc., Dalton Trans. (1990) 3591

[8] G.D. Daves Jr., C.W. Noell, R.K. Robins, H.C. Koppel, A.G. Beaman, J. Am. Chem. Soc. 82 (1960) 2633.

[9] P. Schwab, R.H. Grubbs, J.W. Ziller, J. Am. Chem. Soc. 118 (1996) 100 .

[10] M. Vaarkamp, J.C. Linders, D.C. Koningsberger, Physical B 209 (1995) 159.

[11] M. Vaarkamp, I. Dring, R.J. Oldman, E.A. Stern, D.C. Koningsberger, Phys. Rev. B 50 (1994) 7872.

[12] J.W. Cook Jr., D.E. Sayers, J. Appl. Phys. 52 (1981) 5024.

[13] J.B.A.D. van Zon, D.C. Koningsberger, H.F.J. van 't Blik, D.E. Sayers, J. Chem. Phys. 82 (1985) 5742.

[14] S.I. Zabinsky, J.J. Rehr, A. Ankudinov, R.C. Albers, M.J. Eller, Phys. Rev. B 52 (1995) 2995. 